Article

\title{
The Role of Environment in Sustainable Entrepreneurial Orientation. The Case of Family Firms
}

\author{
Felipe Hernández-Perlines ${ }^{1, *(1)}$ and Manuel Alejandro Ibarra Cisneros ${ }^{2}$ \\ 1 Department of Business Administration, University of Castilla-La Mancha, 45071 Toledo, Spain \\ 2 Faculty of Administrative Sciences, Autonomous University of Baja California, Mexicali 21330, Mexico; \\ manuel_ibarra@uabc.edu.mx \\ * Correspondence: felipe.hperlines@uclm.es; Tel.: +34-925-268-800
}

Received: 22 May 2018; Accepted: 11 June 2018; Published: 15 June 2018

\begin{abstract}
This study analyzes the role of the environment in the sustainable entrepreneurial orientation on the international performance of family firms. The results have been analyzed with Partial Least Squares regression. The three most important contributions of this work are: (1) The definition of sustainable business orientation as a third-order composite that integrates entrepreneurial orientation and corporate social responsibility is adequate as it presents appropriate values of reliability and validity; (2) entrepreneurial orientation is the main component of sustainable entrepreneurial orientation, with having corporate social responsibility a plus for entrepreneurial orientation; and (3) sustainable entrepreneurial orientation manages to explain $58.6 \%$ of the variability in the international performance of family firms and, finally, the environment has a positive moderating role, increasing up to $73.5 \%$.
\end{abstract}

Keywords: sustainable entrepreneurial orientation; environment; international performance; family firms; PLS; moderating effect

\section{Introduction}

In many countries family firms are the most relevant form of enterprise [1-4] because of their capacity to generate both wealth and employment [5-7]. Furthermore, the growth and functioning of many economies is due to the activity of family firms $[8,9]$. This prevalence may be one of the reasons why, in recent years, much of the research on business administration deals with family firms $[10,11]$. Family businesses are an important part of the Spanish economy (see Corona and Del Sol [12]). Among the topics that arouse the interest of researchers of family firms, we identify entrepreneurial orientation [13-16], corporate social responsibility [17-19], and the environment [20-22].

In this work we will analyze the moderating role of the environment in the effect of sustainable entrepreneurial orientation on the international performance of family firms. One of the most relevant contributions of this work centers on sustainable entrepreneurial orientation, which we define as a higher-order concept (third order) that entails the integration of entrepreneurial orientation and corporate social responsibility. Sustainable entrepreneurial orientation is a concept already studied in the literature in a partial manner, either including social aspects of entrepreneurship [23-25] or related environmental issues [26-28]. In this work, we resort to an integrating concept of sustainable entrepreneurial orientation according to the proposal put forward by Criado-Gomis et al. [29], which considers entrepreneurial orientation and corporate social responsibility as primary categories of such a higher-order concept. Criado-Gomis et al. [29] have proposed a categorization and measurement of sustainable entrepreneurial orientation and have called to empirically contrast the definition of 
sustainable entrepreneurial orientation they propose. This research is a response to such a call and intends to empirically verify how sustainable entrepreneurial orientation affects the performance of family firms. The starting point is a previous study by Hernández-Perlines and Rung-Hoch [30], which analyzed the moderating role of entrepreneurial orientation in the effect of corporate social responsibility on performance; although this study referred to sustainable entrepreneurial orientation, entrepreneurial orientation and corporate social responsibility were not jointly analyzed in one same composite. In the present work, entrepreneurial orientation and corporate social responsibility are considered in one same higher-order composite; this being one of the contributions.

The analysis of sustainable entrepreneurial orientation will be carried out at the level of enterprise because it is a strategic orientation $[29,31]$.

The theoretical approach, which supports this work, is that of dynamic capabilities, since sustainable entrepreneurial orientation is a higher-order capability that is the result of the integration of entrepreneurial orientation and corporate social responsibility [29,32], and that adapts to the conditions of the enterprise and the environment [33,34].

Corporate social responsibility has made sustainability become one of the most important business objectives, in general, along with protection to the environment [35]. Concern for sustainability in the sphere of entrepreneurship is relatively recent [36,37]. Scarce are the theoretical and empirical works that offer a clear resolution for the problem [38]. In this regard, we agree with Criado-Gomis et al. [29] on the need to build a clear concept of sustainable entrepreneurial orientation and analyze its consequences. The main goal of this work concurs: Analyze the effect of sustainable entrepreneurial orientation on the international performance of family firms.

Some researchers that analyze sustainable entrepreneurship emphasize the opportunities detected by companies in their search for economic, social, and environmental goals [39]. These goals must be sought jointly, and not independently, because the synergic aggregation of the economic, social, and environmental dimensions allows enterprises to produce value [40]. In this way, there appears what has been called sustainable entrepreneurship [24,37], which means to incorporate the standpoint of sustainability into the entrepreneurship approach [40-43]. If we have an overview of the research on sustainable entrepreneurship, we will observe that most of the work focuses on some of the dimensions, such as the environmental [26-28] or social [23-25]. However, we believe that sustainable entrepreneurship demands a perspective capable of integrating the three dimensions of sustainability according to the proposals by Elkington [43], Telley, and Young [44], Schlange [45], and Criado-Gomis et al. [29].

In this work, we define sustainable entrepreneurial orientation according to Criado-Gomis et al. [29]: As a result of the interaction of entrepreneurial orientation and corporate social responsibility. Sustainable entrepreneurial orientation shows the enterprises' willingness to foster innovative, proactive, and risky actions coherent with the development of economic, social, and environmental aspects of both the company and the environment in which they operate. All in all, sustainable entrepreneurial orientation allows the detection of business opportunities, while considering social and environmental aspects.

The main problem we are faced with in this work is how to make sustainable entrepreneurial orientation operative. We adopted the proposal made by Criado-Gomis et al. [29], who defined sustainable entrepreneurial orientation by means of a categorization process, following the indications underscored by George and Marino [46] and Satori [47]. This way, they consider that sustainable entrepreneurial orientation is a secondary category, which contains all the elements of the main category, entrepreneurial orientation, plus the elements of corporate social responsibility; hence, sustainable entrepreneurial orientation will become operative as a type b, third-order composite, which is the result of adding entrepreneurial orientation as a type $b$, second-order composite and corporate social responsibility as a type a, second-order composite.

Entrepreneurial orientation is one of the key concepts in academic management [20,31,48-51]. This relevance derives from the positive effects of entrepreneurial orientation on the growth of the economy [52], owing to its capacity to generate wealth and employment [53]. 
One of the large problems that concerns family firms is survival. Eddlestton et al. [54] state that many a family firm does not survive the third generation. Considering this, what can be done to solve the problem of the survival of family firms? Some authors argue that such survival depends on how the governance structure affects performance [55]. However, other authors affirm that business behavior affects both the survival [56] and development of family businesses [14,57,58]. But, how to analyze entrepreneurial behavior in family firms? Some authors claim that entrepreneurial orientation is a useful frame to research entrepreneurship in family firms [59-62]. This may be one of the reasons why entrepreneurial orientation has been the object of study of a large number of works on family firms. From the analysis of the literature related to family firms and entrepreneurial orientation, we can state it is not conclusive, owing to the existence of disparate results. Some works state that family firms provide a supportive environment for entrepreneurial activities [13-16,63], while, on the contrary, other researchers state that family firms are, typically, conservative and adverse to risk [1,14]; thereby, despite the noticeable attention paid to entrepreneurial orientation, the debate on its background and consequences is still open [48].

The academic literature has deeply analyzed which dimensions are comprised in entrepreneurial orientation and their relationship [64-67]. In this work, we consider that entrepreneurial orientation is composed of innovativeness, proactiveness, and risk taking. In this sense, we can define entrepreneurial orientation as the decision-making process that seeks new opportunities in an innovative, proactive, and risky manner $[68,69]$. Innovativeness is derived from support for new ideas, experimentation, and creativity [70-72]. Proactiveness is linked with the advantage of being a pioneer and with the search for new commercial opportunities [67,69]. In short, it is about introducing new products and/or services before competitors [49]. Finally, risk taking involves performing actions that require resources, without knowing the benefits that will be accomplished $[67,73]$.

We interpret the concept of entrepreneurial orientation as a multidimensional type $b$, second-order composite (for further information, see Rauch et al. [49], Hansen et al. [74], Covin and Wales [75], and Hernández-Perlines [76]). This is to say, entrepreneurial orientation accounts for entrepreneurial behavior as it benefits from innovation, proactivity, and risk taking (for further reading, see Lumpkin and Dess [67]).

There are many academic papers dealing with entrepreneurial orientation, which is now one of the central topics in literature on companies because of the large amount of knowledge generated [20,31,49,77]. Entrepreneurial orientation has experienced multiple reformulations since its inception. The first author to talk about entrepreneurial orientation was Miller [68], for whom entrepreneurial orientation can be understood as a company's behavior characterized by innovativeness, proactiveness, and risk taking [68]. In the context of competitive aggressiveness, entrepreneurial orientation depends, above all, on the degree of change, innovation, and risk taking [46,78]. On the other hand, entrepreneurial orientation is linked to the ability of the company to innovate, be a pioneer, and take risks in new actions [77]. In short, entrepreneurial orientation is a decision-making process that influences the company's willingness to innovate, to be more proactive than its competitors, and to take risks [70].

The positive relationship between entrepreneurial orientation and firm performance has been proven in numerous studies $[68,69,76,78,79]$.

Economic, social, and environmental scandals have made corporate social responsibility a priority for many managers [17] because it allows "creating shared value" [80], improving the competitiveness of companies in an ever demanding market.

The relationship between corporate social responsibility and performance has been widely analyzed in the literature $[17,81-83]$. In the present investigation, we consider that corporate social responsibility is a source of competitive advantage [84] that positively affects performance [85-90].

Sustainable development requires a convergence between economic development, social equity, and protection of the environment [91]. Therefore, of the multiple definitions of corporate social responsibility, in this work, we used the one that links such a concept with the delivery of sustainability 
reports that provide the different groups of interest, and society as a whole, with information about actions on economic, social, and environmental issues being carried out by the enterprise [92-94].

With regards to the above, we can put forward the hypothesis to be contrasted in this work and which states that both entrepreneurial orientation and corporate social responsibility positively influence the international performance of family firms (There is a high correlation between the firm performance and its international performance.). Therefore, the hypothesis is, as follows:

$\mathbf{H}_{1}$. Sustainable entrepreneurial orientation positively influences the international performance of family firms.

Environment was included to answer the proposal by Hernández-Perlines and Rung-Horch [30], and to analyze its effect. Several works consider that the environment influences the development of the entrepreneurial orientation of enterprises with international activity [20-22]. The analysis of environment can be carried out from two perspectives: (a) environment is analyzed, bearing in mind the dimensions it comprises, such as dynamicity, complexity, hostility, and diversity [95]; and (b) environment is analyzed, bearing in mind the influence of regulatory, normative, and cognitive factors [96].

In this paper, we will focus on the first approach. Out of the four dimensions, hostility and dynamicity have been thoroughly analyzed in several works $[69,97,98]$. Companies must reduce uncertainty by designing models that allow them to manage uncertainty and risk in the decision-making process [99]. In these models, it is necessary to propose an adjustment between the strategy of the company and the environment [100]. In the literature review, we found works that analyze the moderating effect of the environment on entrepreneurial orientation [68,101-103]. There are also distinguishable works that analyze the effect of each dimension of environment on the relation between entrepreneurial orientation and firm performance $[20,58,67,68,103-107]$. The next hypothesis follows from the above:

$\mathbf{H}_{2}$. The environment moderates the influence of sustainable entrepreneurial orientation on the international performance of family firms.

\section{Materials and Methods}

\subsection{Model Proposed}

The research objectives are reflected in the conceptual model proposed. As is shown in Figure 1, this paper aims to analyze the moderating effect of the environment and its influence on the sustainable entrepreneurial orientation of the international performance of family firms. Sustainable entrepreneurial orientation is composed of the integration of entrepreneurial orientation and corporate social responsibility. 


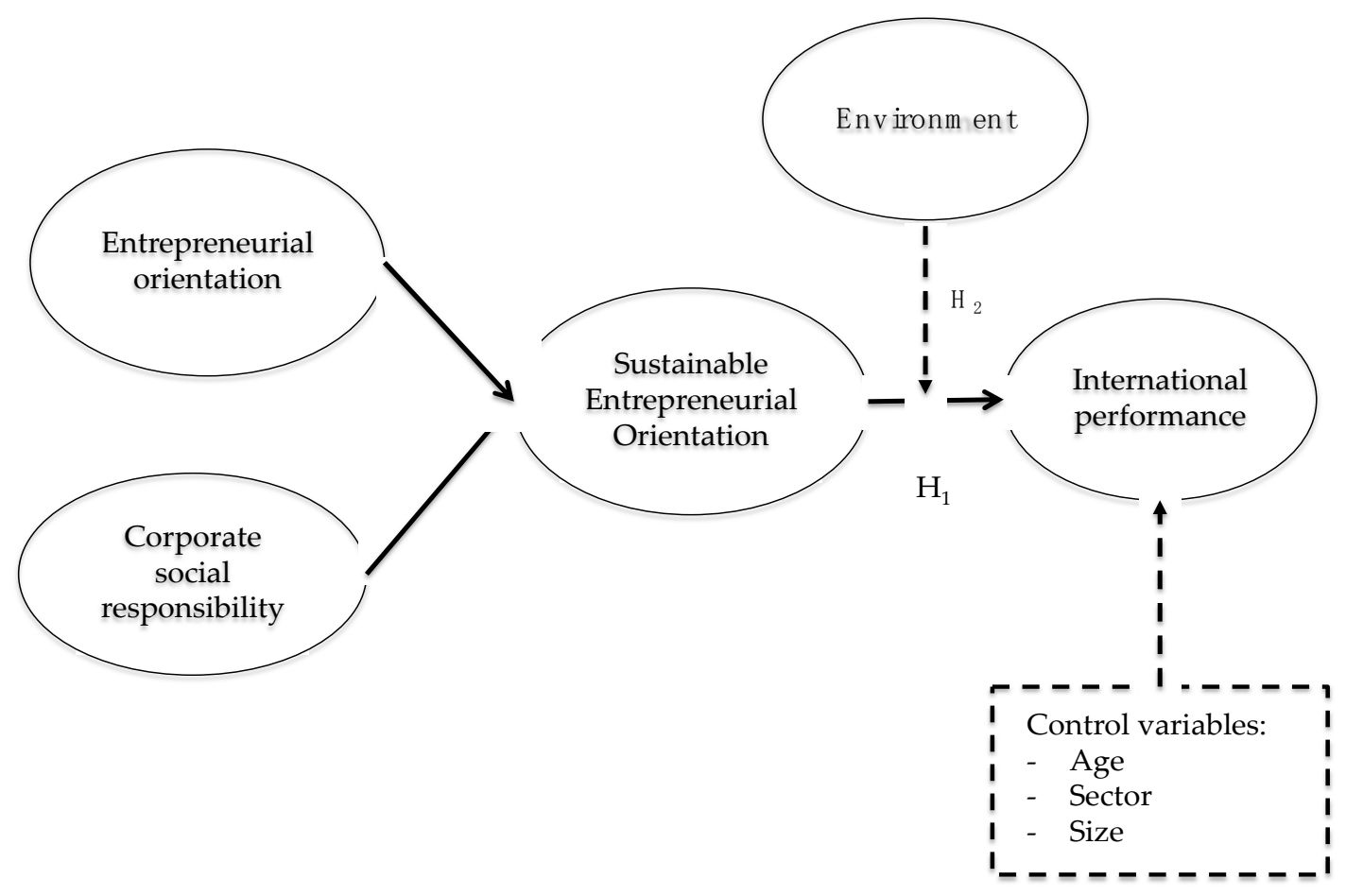

Figure 1. Proposed research model.

\subsection{Data}

Data for entrepreneurial orientation, the environment, and the international performance of family firms were obtained from a questionnaire sent via email using the tool, Limesurvey v. 2.5, to the highest-ranking executives from a sample of enterprises retrieved from the Spanish Institute of Family Firms. The questionnaire contained Likert-type questions (1-5). Data for corporate social responsibility were taken from the sustainability memories published by family firms. After fieldwork, developed between November 2015 and February 2016, 174 questionnaires were obtained with all the answers (see Table 1).

Table 1. Fieldwork data sheet.

\begin{tabular}{cc}
\hline Sample Size & 1.045 \\
Scope of application & Spain \\
Valid answers & 174 \\
Sample processing & Simple random \\
Confidence level & $95 \%, \mathrm{p}=50 \% ; \alpha=0.05$ \\
Response rate & $16.65 \%$ \\
Sampling error & $6.79 \%$ \\
Fieldwork & November 2015-February 2016 \\
\hline
\end{tabular}

The analysis of the statistical power of the sample was carried out with a Cohen's retrospective test [108], through the program, $G^{*}$ Power 3.1.9.2 [109]. In our case, we obtained a value of 0.993 (see Figure 2), with this being higher than the limit of 0.80 established by Cohen [108]). 


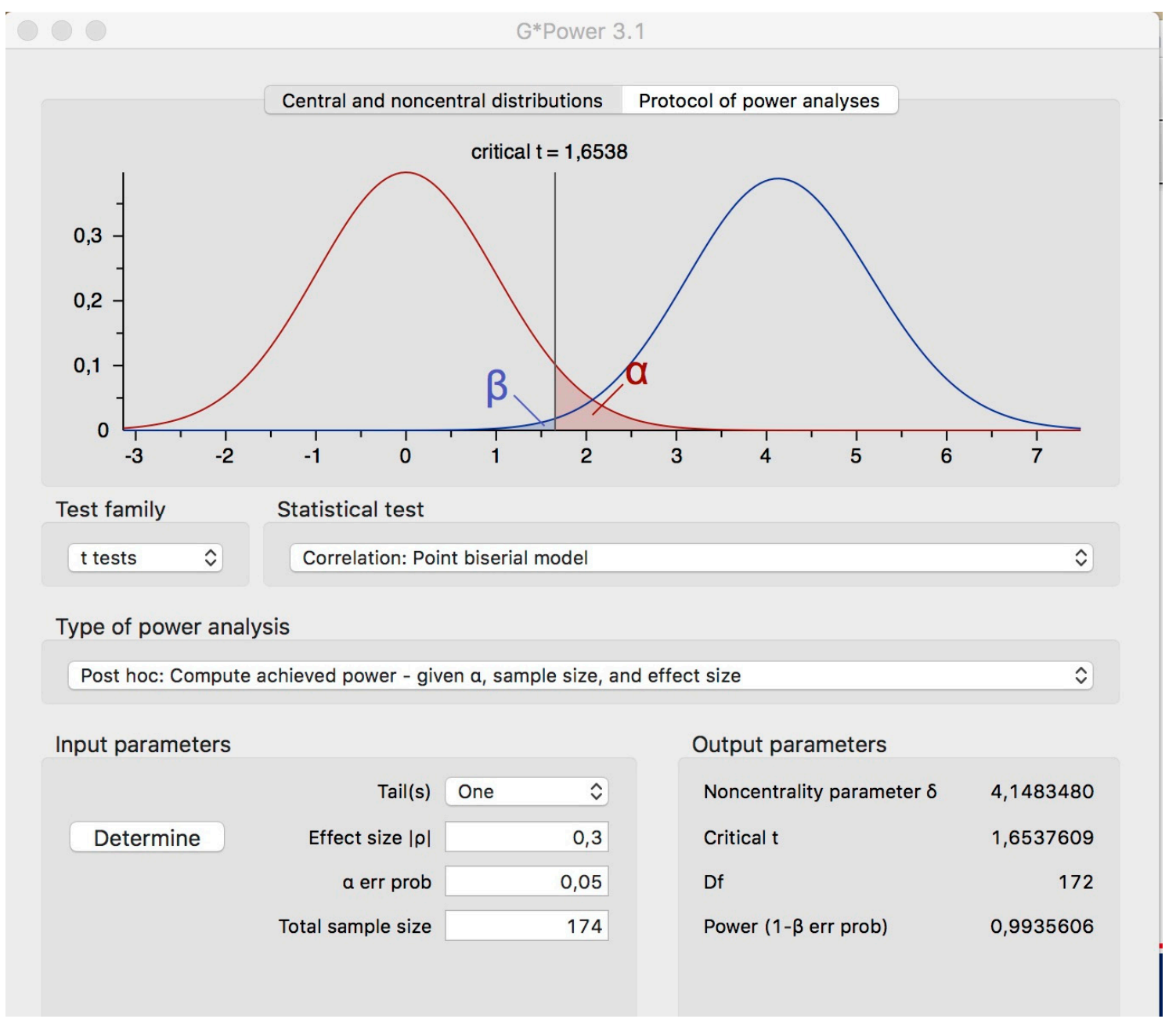

Figure 2. Sample statistical power.

\subsection{Measures of Variables}

\subsubsection{Sustainable Entrepreneurial Orientation}

In this work, we consider sustainable entrepreneurial orientation as a type $b$, third-order composite, generated from entrepreneurial orientation, which is a type $b$, second-order composite, and from corporate social responsibility, which is a type a, second-order composite. Entrepreneurial orientation has been measured using the scale proposed by Miller [68] and modified by Covin and Slevin [69] and Covin and Miller [31], which includes three dimensions: Innovativeness (3 items), proactiveness ( 3 items), and risk taking (3 items). For its part, to measure corporate social responsibility, we have used the triple bottom line (TBL) proposed by Elkington [43] and Chang and Kuo [5]. Corporate social responsibility reflects economic (3 items), social (3 items), and environmental (3 items) dimensions.

\subsubsection{International Performance of Family Firms}

The international performance of family firms became operational as a type a, second-order composite that reflects:

(1) Export intensity, which has been included as a measure of international performance by authors, such as Zahra et al. [21] and Morgan et al. [110]; 
(2) Satisfaction perceived in the exporting performance, which has been included by authors, such as Cavusgil and Zou [111], Balabanis and Katsikea [103], Dimitratos et al. [112], and Zahra et al. [21]; and

(3) International performance refers to exportation results, which has been used by authors, such as Zahra et al. [21] and Morgan et al. [110].

The first two variables were measured using a Likert scale (1-5).

\subsubsection{Environment}

To measure the hostility and dynamism of environment, we used the scales proposed by Robertson and Chetty [113], Balabanis and Katsikeas [103], Dimitratos et al. [112], and Etchebarne et al. [114].

\subsubsection{Control Variables}

For control variables, we resorted to size (number of employees), age (number of years since establishment), and the main activity sector of the family firm, which recurrently appear in studies on family firms [115].

\section{Results}

To contrast the hypotheses and analyze the results, the Partial Least Square (PLS) multivariate quantitative technique of structural equations was used. This method, due to its predictive nature, allows the addressing of the research questions [116,117]. In addition, it allows different causal relationships to be observed [118,119]. Finally, it is less demanding, with regards to the sample size [120]. The software used for SEM-PLS (Structural Equation Modeling-Partial Least Squares) data analysis was SmartPLS v.3.2.7 (SmartPLS GmbH, Boenningstedt, Germany) [121].

The analysis and interpretation of the model was carried out in two steps to ensure that the proposed scales for measurement were valid and reliable [122]: A first analysis of the measurement model and a second analysis of the structural model.

\subsection{Assessment of the Measurement Model}

The reliability of the different composites was verified by analyzing the composite reliability, Cronbach's alpha and the average variance were extracted [123]. The values obtained exceeded the thresholds suggested by the literature $[124,125]$ (see Table 2 ).

Table 2. Composites and indicators.

\begin{tabular}{cccc}
\hline Composite & $\begin{array}{c}\text { Composed } \\
\text { Reliability }\end{array}$ & Cronbach Alpha & AVE $^{\mathbf{a}}$ \\
\hline $\mathrm{SEO}^{1}$ & 0.747 & 0.792 & 0.694 \\
$\mathrm{EO}^{2}$ & 0.850 & 0.733 & 0.756 \\
$\mathrm{CSR}^{3}$ & 0.827 & 0.882 & 0.809 \\
$\mathrm{EN}^{4}$ & 0.937 & 0.866 & 0.882 \\
$\mathrm{IPF}^{5}$ & 0.744 & 0.780 & 0.695 \\
\hline
\end{tabular}

Note: ${ }^{1}$ Sustainable entrepreneurial orientation; ${ }^{2}$ entrepreneurial orientation; ${ }^{3}$ corporate social responsibility;

${ }^{4}$ environment; ${ }^{5}$ international performance of family firms. ${ }^{a}$ average variance extracted.

On the other hand, discriminant validity measures the difference between the composites considered [117]. We compared the values of the square root of AVE for each compound with the correlations between them [125]. As displayed in Table 3, the values of AVE for all the composites were greater than the correlations between them. 
Table 3. Discriminant validity ${ }^{(a)}$.

\begin{tabular}{cccccc}
\hline & SEO $^{\mathbf{1}}$ & $\mathrm{CSR}^{2}$ & EO $^{\mathbf{3}}$ & EN $^{\mathbf{4}}$ & IPF $^{\mathbf{5}}$ \\
\hline $\mathrm{SEO}^{1}$ & $\mathbf{0 . 8 3 3}$ & & & & \\
$\mathrm{CSR}^{2}$ & 0.642 & $\mathbf{0 . 8 9 9}$ & & & \\
$\mathrm{EO}^{3}$ & 0.701 & 0.647 & $\mathbf{0 . 8 6 9}$ & & \\
$\mathrm{EN}^{4}$ & 0.548 & 0.684 & 0.563 & $\mathbf{0 . 9 3 9}$ & \\
$\mathrm{IPF}^{5}$ & 0.687 & 0.713 & 0.671 & 0.695 & $\mathbf{0 . 8 3 3}$ \\
\hline
\end{tabular}

Note: $\left({ }^{*}\right)$ The square root of AVE was calculated on the diagonal (in bold). ${ }^{(a)}$ The values have been calculated for the second and third order composites. ${ }^{1}$ Sustainable entrepreneurial orientation; ${ }^{2}$ entrepreneurial orientation;

${ }^{3}$ corporate social responsibility; ${ }^{4}$ environment; ${ }^{5}$ international performance of family firms.

Another indicator of validity is the HTMT (Heterotrait-Monotrait Ratio of Correlations) ratio. Such a ratio allows calculating the discriminant validity between indicators of the same composite and between indicators of different composites. Discriminant validity is met when the values of the HTMT ratio are under 0.85 [120], as it was in our study (see Table 4).

Table 4. Ratio Heterotrait-monotrait (HTMT).

\begin{tabular}{llllll}
\hline & SEO $^{1}$ & CSR $^{2}$ & EO $^{3}$ & EN $^{4}$ & IPF $^{5}$ \\
\hline $\mathrm{SEO}^{1}$ & & & & & \\
$\mathrm{CSR}^{2}$ & 0.676 & & & & \\
$\mathrm{EO}^{3}$ & 0.784 & 0.743 & & & \\
$\mathrm{EN}^{4}$ & 0.687 & 0.712 & 0.693 & & \\
$\mathrm{IPF}^{5}$ & 0.610 & 0.636 & 0.702 & 0.698 & \\
\hline
\end{tabular}

Note: ${ }^{1}$ Sustainable entrepreneurial orientation; ${ }^{2}$ entrepreneurial orientation; ${ }^{3}$ corporate social responsibility;

${ }^{4}$ environment; ${ }^{5}$ international performance of family firms.

Finally, to analyze the discriminant validity, we calculated the $\mathrm{HTMT}_{\text {inference }}$ from a start of 5000 subsamples. Discriminant validity occurs when the resulting interval contains values under 1 . As is shown in Table 5, there is discriminant validity.

Table 5. $\mathrm{HTMT}_{\text {inference. }}$

\begin{tabular}{ccccccccc}
\hline & $\begin{array}{c}\text { Original } \\
\text { Data (O) }\end{array}$ & $\begin{array}{c}\text { Mean of } \\
\text { Data (M) }\end{array}$ & $\mathbf{5 . 0 \%}$ & $\mathbf{9 5 . 0 \%}$ & $\begin{array}{c}\text { Mean of } \\
\text { Data (M) }\end{array}$ & Bias & $\mathbf{5 . 0 \%}$ & $\mathbf{9 5 . 0 \%}$ \\
\hline $\mathrm{CSR}^{3} \Rightarrow \mathrm{SEO}^{1}$ & 0.636 & 0.622 & 0.275 & 0.657 & 0.622 & -0.014 & 0.277 & 0.658 \\
$\mathrm{EO}^{2} \Rightarrow \mathrm{SEO}^{1}$ & 0.702 & 0.696 & 0.258 & 0.758 & 0.696 & -0.006 & 0.247 & 0.754 \\
$\mathrm{SEO}^{2} \Rightarrow \mathrm{IPF}^{5}$ & 0.707 & 0.706 & 0.635 & 0.770 & 0.706 & 0.001 & 0.630 & 0.767 \\
$\mathrm{EN}^{4} \Rightarrow \mathrm{IPF}^{5}$ & 0.902 & 0.908 & 0.882 & 0.928 & 0.908 & 0.006 & 0.882 & 0.928 \\
\hline
\end{tabular}

Note: ${ }^{1}$ Sustainable entrepreneurial orientation; ${ }^{2}$ entrepreneurial orientation; ${ }^{3}$ corporate social responsibility;

${ }^{4}$ environment; ${ }^{5}$ international performance of family firms.

Therefore, we can affirm that all the proposed composites are reliable and have discriminant validity.

It is necessary to validate entrepreneurial orientation as it is a type b, second-order composite [126]. For this, we have followed the recommendations of Diamantopoulos et al. [127]. In both cases, the indicators in each construction should have no collinearity problems [128]; collinearity problems may arise when the variance inflation factor (VIF) reaches or surpasses the value of 5 [129]. As is shown in Table 6, there are no collinearity problems. 
Table 6. Collinearity of type b composites.

\begin{tabular}{ccc}
\hline & EO $^{2}$ \\
\hline Factor & Loads $(\boldsymbol{\lambda})$ & VIF \\
\hline Innovativeness & 0.478 & 1.905 \\
Proactiveness & 0.429 & 1.703 \\
Risk taking & 0.308 & 1.28 \\
\hline \multicolumn{3}{c}{ SEO $^{\mathbf{1}}$} \\
\hline Factor $^{2}$ & Loads $\left.^{2} \boldsymbol{\lambda}\right)$ & VIF \\
$\mathrm{CSR}^{3}$ & 0.632 & 2.253 \\
\hline
\end{tabular}

Note: ${ }^{1}$ Sustainable entrepreneurial orientation; ${ }^{2}$ entrepreneurial orientation; ${ }^{3}$ corporate social responsibility.

\subsection{Assessment of the Structural Model}

The analysis of the structural model verifies that sustainable entrepreneurial orientation has a positive impact on the international performance of family firms. The path coefficient is 0.404 (over 0.2 , Chin's [130] lowest limit). Moreover, this effect is significant (the value of $t$ is 8.563, based on $t$ (4999) of a tailed test at a significance level of $p<0.001$ ), while sustainable entrepreneurial orientation explained $58.6 \%$ of the variance of the international performance of family firms.

The environment also positively affected the international performance of family firms, with a path coefficient of 0.395 . This positive effect anticipates the moderating effect of the environment in the influence of sustainable entrepreneurial orientation on the international performance of family firms. This way, we verify that the environment positively moderates the influence of the international performance of family firms as it explained $73.5 \%$ of the variance of such performance (see Table 7).

Table 7. Structural model.

\begin{tabular}{ccccc}
\hline & $\mathbf{R}^{2}$ & $\mathbf{B}$ & $\boldsymbol{t}$-Value & Support \\
\hline $\mathrm{SEO}^{1} \Rightarrow \mathrm{IPF}^{5}$ & 0.586 & 0.404 & 8.563 & Yes \\
\hline $\mathrm{SEO}^{1} \Rightarrow \mathrm{IPF}^{5}$ & \multirow{2}{*}{0.647} & 0.482 & 6.681 & \\
$\mathrm{EN}^{4} \Rightarrow \mathrm{IPF}^{5}$ & & 0.395 & 5.854 & \\
\hline & & 0.375 & 9.837 & \multirow{2}{*}{$\mathrm{SEO}^{1} \times \mathrm{EN}^{4} \Rightarrow \mathrm{IPF}^{5}$} \\
& 0.735 & 0.412 & 7.543 & Yes
\end{tabular}

Note: ${ }^{1}$ Sustainable entrepreneurial orientation; ${ }^{2}$ entrepreneurial orientation; ${ }^{3}$ corporate social responsibility; ${ }^{4}$ environment; ${ }^{5}$ international performance of family firms.

The control variables were not relevant or significant, since path coefficients were lower than 0.2 and the values of $t$ were lower than the recommended value (see Table 8).

Table 8. Control variables.

\begin{tabular}{ccc}
\hline Variable & $\boldsymbol{B}$ & $\boldsymbol{t}$-Value \\
\hline Age & -0.086 & 0.976 \\
Sector & -0.089 & 0.751 \\
Size & -0.072 & 0.864 \\
\hline
\end{tabular}

Finally, the goodness of fit of the model was calculated from the standardized root mean residue (SRMR) $[120,131]$. In our model, SRMR obtained a value of 0.063 , which is below the value of 0.08 recommended by Henseler et al. [120]. 


\section{Discussion}

The first aspect that we can highlight in this work refers to the reliability and validity of the composites considered. Entrepreneurial orientation, corporate social responsibility, environment, and the international performance of family firms exhibited adequate values of validity and reliability. Besides, the composite sustainable entrepreneurial orientation, proposed by Criado-Gomis et al. [29], also displayed adequate values of validity and reliability, following entrepreneurial orientation and corporate social responsibility, which also did. This means that we can use this concept to empirically contrast its effect, in our case, on the international performance of family firms. Of the two components that integrate sustainable entrepreneurial orientation, entrepreneurial orientation was the most relevant, since the path coefficient was 0.632 before 0.529 for corporate social responsibility. This result verifies that entrepreneurial orientation is the main category of sustainable entrepreneurial orientation, as stated by Criado-Gomis et al. [29]. The measure of entrepreneurial orientation, according to the scale proposed by Miller [68], Covin and Slevin [69], and Covin and Miller [31], that influences innovativeness, proactiveness, and risk taking was adequate. On the other hand, corporate social responsibility, as measured by means of the triple count of GRI (Global Reporting Initiative) is also adequate [92-94]. The utilization of a multi-item scale for the international performance of family firms in this work was suitable [21,110-112], since it presented adequate values of reliability and validity. The proposed measure of environment $[103,112-114]$ was relevant as it presented adequate values of reliability and validity.

Sustainable entrepreneurial orientation positively influenced the international performance of family firms and explained $58.6 \%$ of the variance of the international performance of family firms. This positive effect of sustainable entrepreneurial orientation was expected, as, in previous works, entrepreneurial orientation $[68,70,76,78]$ and corporate social responsibility [79-83] have positively influenced the performance of family firms. Hereby, we have responded to Criado-Gomis et al. [29], as we empirically contrasted the composed effect of sustainable entrepreneurial orientation; we deem this as one of the most relevant contributions of this research.

The environment positively influenced the international performance of family firms, since the path coefficient was 0.395 . This positive effect has already been verified in previous works $[58,103,105]$. When we consider sustainable entrepreneurial orientation and the environment, the explained variance of the international performance of family firms changes to $64.47 \%$. With the inclusion of the environment into the analysis, we addressed the future research line proposed by Hernández-Perlines and Rung [30].

After analyzing the moderating effect of the environment, we verify that it acted as a positive moderator of the influence of sustainable entrepreneurial orientation on the international performance of family firms, as demonstrated by the positive path coefficient $(0.290)$, and that the explained variance of performance changes to $73.5 \%$.

The proposed moderating model presents a good fit, measured from the standardized root mean residual (SRMR). The model accomplished an SRMR of 0.063, lower than those specified in the literature [120].

The limitations of this work come from the configuration of entrepreneurial orientation and corporate social responsibility, which would affect the definition of sustainable entrepreneurial orientation. Each of the dimensions could have been independently specified (innovation, proactivity, and risk taking for entrepreneurial orientation, and the economic, social, and environmental dimensions for corporate social responsibility) and verify the effect of each one on sustainable entrepreneurial orientation, and analyze the moderating effect of each of the dimensions of entrepreneurial orientation. Another limitation comes from the non-consideration of the effect of the internal variables of the family firms, such as the generational level, separation between property and control, and gender at direction and property. Another limitation is that we considered the situation of the country of origin, not the destination of international activity 
As future research, we propose to analyze the influence of sustainable entrepreneurial orientation on various ways to specify the performance of family firms (innovative performance, overall performance). In addition, it would be interesting to analyze the effects of sustainable entrepreneurial orientation on non-family firms and draw comparisons to find out whether it behaves differently. Another research line would be to analyze the influence of sustainable entrepreneurial orientation on other dynamical capabilities, such as absorption or learning. On the other hand, it is proposed to analyze how sustainable entrepreneurial orientation determines joint learning and the development of new sources of competitiveness in companies with cooperation agreements [132]. It could also be analyzed how it affects the regulatory activity in sustainable entrepreneurial orientation [133]. Finally, a bidirectional study between sustainable entrepreneurial orientation and the performance of the family business is proposed as a future research line [90].

Author Contributions: All authors listed have made substantial, direct and intellectual contributions to the work and approved it for publication.

Funding: This research received no external funding.

Conflicts of Interest: The authors declare no conflict of interest.

\section{References}

1. Gómez-Mejía, L.R.; Haynes, K.T.; Nunez-Nickel, M.; Jacobson, K.J.; Moyano-Fuentes, J. Socioemotional wealth and business risks in family-controlled firms: Evidence from Spanish olive oil mills. Adm. Sci. $Q$. 2007, 52, 106-137. [CrossRef]

2. Masulis, R.W.; Pham, P.K.; Zein, J. Family firm groups around the world: Financing advantages, control motivations, and organizational choices. Rev. Financ. Stud. 2011, 24, 3556-3600. [CrossRef]

3. Gedajlovic, E.; Carney, M.; Chrisman, J.J.; Kellermanns, F.W. The adolescence of family firm research taking stock and planning for the future. J. Manag. 2012, 38, 1010-1037. [CrossRef]

4. Poza, E.J.; Daugherty, M.S. Family Firm, 4th ed.; Cengage Learning: Mason, OH, USA, 2013.

5. Chang, E.P.; Memili, E.; Chrisman, J.J.; Kellermanns, F.W.; Chua, J.H. Family social capital, venture preparedness, and start-up decisions: A study of Hispanic entrepreneurs in New England. Fam. Firm Rev. 2009, 22, 279-292. [CrossRef]

6. Fan, J.P.; Wei, K.J.; Xu, X. Corporate finance and governance in emerging markets: A selective review and an agenda for future research. J. Corp. Financ. 2011, 2, 207-214. [CrossRef]

7. Matthews, C.H.; Echavarria, D.; Schenkel, M.T. Family Firm: A Global Perspective from the Panel Study of Entrepreneurial Dynamics and the Global Entrepreneurship Monitor, Understanding Family Firmes (9-26); Carsrud, A.L., Brännback, M., Eds.; Springer: New York, NY, USA, 2012.

8. Astrachan, J.H.; Shanker, M.C. Family firmes' contribution to the US economy: A closer look. Fam. Firm Rev. 2003, 16, 211-219. [CrossRef]

9. Memili, E.; Fang, H.; Chrisman, J.J.; De Massis, A. The impact of small-and medium-sized family firms on economic growth. Small Bus. Econ. 2015, 45, 771-785. [CrossRef]

10. Chrisman, J.J.; Kellermanns, F.W.; Chan, K.C.; Liano, K. Intellectual foundations of current research in family firm: An identification and review of 25 influential articles. Fam. Firm Rev. 2010, 23, 9-26. [CrossRef]

11. Sharma, P.; Chrisman, J.J.; Gersick, K.E. 25 years of family firm review: Reflections on the past and perspectives for the future. Fam. Firm Rev. 2012, 25, 5-15. [CrossRef]

12. Corona, J.; Del Sol, I. La Empresa Familiar en España (2015); Instituto de la Empresa Familiar: Barcelona, Spain, 2016.

13. Aldrich, H.E.; Cliff, J.E. The pervasive effects of family on entrepreneurship: Toward a family embeddedness perspective. J. Bus. Ventur. 2003, 18, 573-596. [CrossRef]

14. Zahra, S.A.; Hayton, J.C.; Salvato, C. Entrepreneurship in family vs. non-family firms: A resource-based analysis of the effect of organizational culture. Entrep. Theory Pract. 2004, 28, 363-381. [CrossRef]

15. Eddleston, K.A.; Kellermanns, F.W.; Sarathy, R. Resource configuration in family firms: Linking resources, strategic planning and technological opportunities to performance. J. Manag. Stud. 2008, 45, 26-50. [CrossRef]

16. Hernández-Perlines, F.; Moreno-García, J.; Yáñez-Araque, B. Using fuzzy-set qualitative comparative analysis to develop an absorptive capacity-based view of training. J. Bus. Res. 2016, 69, 1510-1515. [CrossRef] 
17. Lu, W.; Chau, K.W.; Wang, H.; Pan, W. A decade's debate on the nexus between corporate social and corporate financial performance: A critical review of empirical studies 2002-2011. J. Clean. Prod. 2014, 79, 195-206. [CrossRef]

18. Lozano, R.; Carpenter, A.; Huisingh, D. A review of 'theories of the firm' and their contributions to Corporate Sustainability. J. Clean. Prod. 2015, 106, 430-442. [CrossRef]

19. Herrera-Madueño, J.; Larrán-Jorge, M.; Martínez-Conesa, I.; Martínez-Martínez, D. Relationship between corporate social responsibility and competitive performance in Spanish SMEs: Empirical evidence from a stakeholders' perspective. BRQ Bus. Res. Q. 2016, 19, 55-72. [CrossRef]

20. Covin, J.G.; Slevin, D.P. A conceptual model of entrepreneurship as firm behavior. Entrep. Theory Pract. 1991, 16,7-25. [CrossRef]

21. Zahra, S.A.; Neubaum, D.O.; Huse, M. The effect of the environment on export performance among telecommunications new ventures. Entrep. Theory Pract. 1997, 22, 25-46. [CrossRef]

22. Kreiser, P.M.; Marino, L.D.; Dickson, P.; Weaver, K.M. Cultural influences on entrepreneurial orientation: The impact of national culture on risk taking and proactiveness in SMEs. Entrep. Theory Pract. 2010, 34, 959-983. [CrossRef]

23. Nicolls, A. Social Entrepreneurship—New Models of Sustainable Social Change; Oxford University Press: Oxford, UK, 2006.

24. Beltz, F.M.; Binder, J.K. Sustainable entrepreneurship: A convergent process model. Bus. Strategy Environ. 2017, 26, 1-17. [CrossRef]

25. Prahalad, C.K.; Hammond, A. Serving the world's poor, profitably. Harv. Bus. Rev. 2002, 80, 48-59. [PubMed]

26. Schaltegger, S. A framework for ecopreneurship: Leading bioneers and environmental managers to ecopreneurship. Greener Manag. Int. 2002, 38, 45-58. [CrossRef]

27. O`Neill, K.; Gibbs, D. Rethinking Green Entrepreneurship-Fluid Narratives of the Green Economy. Environ. Plan. 2016, 48, 1727-1749. [CrossRef]

28. Ndubisi, N.O.; Nair, S.R. Green Entrepreneurship (GE) and Green Value Added (GVA): A conceptual framework. Int. J. Entrep. 2009, 13, 21-34.

29. Criado-Gomis, A.; Cervera-Taulet, A.; Iniesta-Bonillo, M.A. Sustainable Entrepreneurial Orientation: A Business Strategic Approach for Sustainable Development. Sustainability 2017, 9, 1667. [CrossRef]

30. Hernández-Perlines, F.; Rung-Hoch, N. Sustainable entrepreneurial orientation in family firms. Sustainability 2017, 9, 1212. [CrossRef]

31. Covin, J.G.; Miller, D. International entrepreneurial orientation: Conceptual considerations, research themes, measurement issues, and future research directions. Entrep. Theory Pract. 2014, 38, 11-44. [CrossRef]

32. Winter, S.G. Understanding dynamic capabilities. Strateg. Manag. J. 2003, 24, 991-995. [CrossRef]

33. Wang, C.L.; Ahmed, P.K. The development and validation of the organizational innovativeness construct using confirmatory factor analysis. Eur. J. Innov. Manag. 2004, 7, 303-313. [CrossRef]

34. Day, G.S. The capabilities of market-driven organizations. J. Mark. 1994, 58, 37-52. [CrossRef]

35. Zavadskas, E.K.; Govindan, K.; Antucheviciene, J.; Turskis, Z. Hybrid multiple criteria decision-making methods: A review of applications for sustainability issues. Econ. Res. Ekon. Istraž. 2016, 29, 857-887. [CrossRef]

36. Kuckertz, A.; Wagner, M. The influence of sustainability orientation on entrepreneurial intentions-Investigating the role of business experience. J. Bus. Ventur. 2010, 25, 524-539. [CrossRef]

37. Shepherd, D.A.; Patzelt, H. Researching Entrepreneurships' Role in Sustainable Development. In Trailblazing in Entrepreneurship; Palgrave MacMillan: Cham, Switzerland, 2017; pp. 149-179.

38. Hockerts, K.; Wüstenhagen, R. Greening Goliaths versus emerging Davids-Theorizing about the role of incumbents and new entrants in sustainable entrepreneurship. J. Bus. Ventur. 2010, 25, 481-492. [CrossRef]

39. Cohen, B.; Smith, B.; Mitchell, R. Toward a sustainable conceptualization of dependent variables in entrepreneurship research. Bus. Strategy Environ. 2008, 17, 107-119. [CrossRef]

40. Cohen, B.; Winn, M.I. Market imperfections, opportunity and sustainable entrepreneurship. J. Bus. Ventur. 2007, 22, 29-49. [CrossRef]

41. Dean, T.J.; McMullen, J.S. Toward a theory of sustainable entrepreneurship: Reducing environmental degradation through entrepreneurial action. J. Bus. Ventur. 2007, 22, 50-76. [CrossRef]

42. Stål, H.I.; Bonnedahl, K. Conceptualizing strong sustainable entrepreneurship. Small Enterp. Res. 2016, 23, 73-84. [CrossRef] 
43. Elkington, J. Enter the Triple Bottom Line. In The Triple Bottom Line, Does It All Add Up? Assessing the Sustainability of Business and CSR; Henriques, A., Richardson, J., Eds.; Earthscan Publications Ltd.: London, UK, 2004; pp. 1-16.

44. Tilley, F.; Young, W. Sustainability entrepreneurs. Could they be the true wealth generators of the future? Greener Manag. Int. 2009, 55, 79-92.

45. Schlange, L.E. Stakeholder identification in sustainability entrepreneurship. The role of managerial and organizational cognition. Greener Manag. Int. 2006, 55, 13-32. [CrossRef]

46. George, B.A.; Marino, L. The epistemology of entrepreneurial orientation: Conceptual formation, modeling, and operationalization. Entrep. Theory Pract. 2011, 35, 989-1024. [CrossRef]

47. Satori, G. Concept mis formation in comparative politics. Am. Political Sci. Rev. 1970, 64, $1033-1053$. [CrossRef]

48. Miller, D. Miller (1983) revisited: A reflection on EO research and some suggestions for the future. Entrep. Theory Pract. 2011, 35, 873-894. [CrossRef]

49. Rauch, A.; Wiklund, J.; Lumpkin, G.T.; Frese, M. Entrepreneurial orientation and business performance: An assessment of past research and suggestions for the future. Entrep. Theory Pract. 2009, 33, 761-787. [CrossRef]

50. Roig Dobon, S.; Ribeiro Soriano, D. Exploring alternative approaches in service industries: The role of entrepreneurship. Serv. Ind. J. 2008, 28, 877-882. [CrossRef]

51. Wales, W.; Monsen, E.; McKelvie, A. The organizational pervasiveness of entrepreneurial orientation. Entrep. Theory Pract. 2011, 35, 895-923. [CrossRef]

52. Méndez-Picazo, M.T.; Galindo-Martín, M.Á.; Ribeiro-Soriano, D. Governance, entrepreneurship and economic growth. Entrep. Reg. Dev. 2012, 24, 865-877. [CrossRef]

53. Ribeiro-Soriano, D.; Peris-Ortiz, M. Subsidizing technology: How to succeed. J. Bus. Res. 2011, 64, 1224-1228. [CrossRef]

54. Eddleston, K.A.; Kellermanns, F.W.; Floyd, S.W.; Crittenden, V.L.; Crittenden, W.F. Planning for growth: Life stage differences in family firms. Entrep. Theory Pract. 2013, 37, 1177-1202. [CrossRef]

55. González, A.C.; Rodriguez, Y.E.; Sossa, A. Leadership and Governance Decisions in Family Business Performance: An Application of Fuzzy Sets Logic. J. Small Bus. Strategy 2017, 27, 51-66.

56. Kellermanns, F.W.; Eddleston, K.A. Corporate entrepreneurship in family firms: A family perspective. Entrep. Theory Pract. 2006, 30, 809-830. [CrossRef]

57. Zahra, S.A. Governance, ownership, and corporate entrepreneurship: The moderating impact of industry technological opportunities. Acad. Manag. J. 1996, 39, 1713-1735.

58. Casillas, J.C.; Moreno, A.M. The relationship between entrepreneurial orientation and growth: The moderating role of family involvement. Entrep. Reg. Dev. 2010, 22, 265-291. [CrossRef]

59. Zahra, S.A. Entrepreneurial risk taking in family firms. Fam. Firm Rev. 2005, 18, 23-40. [CrossRef]

60. Naldi, L.; Nordqvist, M.; Sjöberg, K.; Wiklund, J. Entrepreneurial orientation, risk taking, and performance in family firms. Fam. Firm Rev. 2007, 20, 33-47. [CrossRef]

61. Kellermanns, F.W.; Eddleston, K.A.; Zellweger, T.M. Extending the socioemotional wealth perspective: A look at the dark side. Entrep. Theory Pract. 2012, 36, 1175-1182. [CrossRef]

62. Cruz, C.; Nordqvist, M. Entrepreneurial orientation in family firms: A generational perspective. Small Bus. Econ. 2012, 38, 33-49. [CrossRef]

63. Zahra, S.A.; Hayton, J.C.; Neubaum, D.O.; Dibrell, C.; Craig, J. Culture of family commitment and strategic flexibility: The moderating effect of stewardship. Entrep. Theory Pract. 2008, 32, 1035-1054. [CrossRef]

64. Covin, J.G.; Green, K.M.; Slevin, D.P. Strategic process effects on the entrepreneurial orientation-sales growth rate relationship. Entrep. Theory Pract. 2006, 30, 57-81. [CrossRef]

65. Knight, G.A. Cross-cultural reliability and validity of a scale to measure firm entrepreneurial orientation. J. Bus. Ventur. 1997, 12, 213-225. [CrossRef]

66. Kreiser, P.M.; Marino, L.D.; Weaver, K.M. Assessing the psychometric properties of the entrepreneurial orientation scale: A multicountry analysis. Entrep. Theory Pract. 2002, 26, 71-94. [CrossRef]

67. Lumpkin, G.T.; Dess, G.G. Clarifying the entrepreneurial orientation construct and linking it to performance. Acad. Manag. Rev. 1996, 21, 135-172. [CrossRef]

68. Miller, D. The correlates of entrepreneurship in three types of firms. Manag. Sci. 1983, 29, 770-791. [CrossRef]

69. Covin, J.G.; Slevin, D.P. Strategic management of small firms in hostile and benign environments. Strateg. Manag. J. 1989, 10, 75-87. [CrossRef] 
70. Miller, D.; Friesen, P. Strategy making and environment: The third link. Strateg. Manag. J. 1983, 4, $221-235$. [CrossRef]

71. Kropp, F.; Lindsay, N.J.; Shoham, A. Entrepreneurial, market, and learning orientations and international entrepreneurial business venture performance in South African firms. Int. Market. Rev. 2006, 23, 504-523. [CrossRef]

72. Chandra, Y.; Styles, C.; Wilkinson, I. The recognition of first time international entrepreneurial opportunities: Evidence from firms in knowledge-based industries. Int. Market. Rev. 2009, 26, 30-61. [CrossRef]

73. Krauss, S.; Frese, M.; Friedrich, C.; Unger, J. Entrepreneurial orientation: A psychological model successamong southern African small business owners. Eur. J. Work Organ. Psychol. 2005, 14, 315-344. [CrossRef]

74. Hansen, J.D.; Deitz, G.D.; Tokman, M.; Marino, L.D.; Weaver, K.M. Cross-national invariance of the entrepreneurialorientation scale. J. Bus. Ventur. 2001, 26, 61-78. [CrossRef]

75. Covin, J.G.; Wales, W.J. The measurement of entrepreneurial orientation. Entrep. Theory Pract. 2012, 36, 677-702. [CrossRef]

76. Hernández-Perlines, F. Entrepreneurial orientation in hotel industry: Multi-group analysis of quality certification. J. Bus. Res. 2016, 69, 4714-4724. [CrossRef]

77. Engelen, A.; Gupta, V.; Strenger, L.; Brettel, M. Entrepreneurial orientation, firm performance, and the moderating role of transformational leadership behaviors. J. Manag. 2015, 41, 1069-1097. [CrossRef]

78. Wiklund, J.; Shepherd, D. Entrepreneurial orientation and small business performance: A configurational approach. J. Bus. Ventur. 2005, 20, 71-91. [CrossRef]

79. Pett, T.; Wolff, J.A. Entrepreneurial orientation and learning in high and low-performing SMEs. J. Small Bus. Strategy 2016, 26, 71-86.

80. Escalonilla-Solano, S.; Plaza-Casado, P.; Ureba, S.F. Análisis de la divulgación de la información sobre la responsabilidad social corporativa en las empresas de transporte público urbano en España. Revista de Contabilidad 2016, 19, 195-203. [CrossRef]

81. Margolis, J.D.; Walsh, J.P. Misery Loves Companies: Rethinking Social Initiatives by Business. Adm. Sci. Q. 2003, 48, 268-305. [CrossRef]

82. Orlitzky, M.; Schmidt, F.L.; Rynes, S.L. Corporate Social and Financial Performance: A Meta-Analysis. Organ. Stud. 2003, 24, 403-441. [CrossRef]

83. Wu, M.L. Corporate social performance, corporate financial performance, and firm size: A meta-analysis. J. Am. Acad. Bus. 2006, 8, 163-171.

84. Alvarado Herrera, A.; Bigné Alcañiz, E.; Currás Pérez, R. Theoretical perspectives for studying corporate social responsibility: A rationality-based classification. Estud. Gerenc. 2011, 27, 115-138.

85. Garcia-Castro, R.; Ariño, M.A.; Canela, M.A. Does social performance really lead to financial performance? Accounting for endogeneity. J. Bus. Ethics 2010, 92, 107-126. [CrossRef]

86. Mar Miras-Rodríguez, M.; Carrasco-Gallego, A.; Escobar-Pérez, B. Are Socially Responsible Behaviors Paid Off Equally? A Cross-cultural Analysis. Corp. Soc. Responsib. Environ. Manag. 2015, 22, 237-256. [CrossRef]

87. Martínez-Campillo, A.; Cabeza-García, L.; Marbella-Sánchez, F. Responsabilidad social corporativa y resultado financiero: Evidencia sobre la doble dirección de la causalidad en el sector de las Cajas de Ahorros. Cuadernos de Economía y Dirección de la Empresa 2013, 16, 54-68. [CrossRef]

88. Li, F.; Li, T.; Minor, D. CEO power, corporate social responsibility, and firm value: A test of agency theory. Int. J. Manag. Financ. 2016, 12, 611-628. [CrossRef]

89. Hernández-Perlines, F. Influencia de la responsabilidad social en el desempeño de las empresas familiares. Revista de Globalización Competitividad y Gobernabilidad 2017, 11, 58-73.

90. Cuomo, M.T.; Tortora, D.; Mazzucchelli, A.; Festa, G.; Di Gregorio, A.; Metallo, G. Impacts of Code of ethics on financial performance in the Italian listed companies of bank sector. J. Bus. Account. Financ. Perspect. 2018, in press. [CrossRef]

91. Mikušová, M. To be or not to be a business responsible for sustainable development? Survey from small Czech businesses. Econ. Res. Ekon. Istraž. 2017, 30, 1318-1338. [CrossRef]

92. Gamerschlag, R.; Möller, K.; Verbeeten, F. Determinants of voluntary CSR disclosure: Empirical evidence from Germany. Rev. Manag. Sci. 2011, 5, 233-262. [CrossRef]

93. Campopiano, G.; De Massis, A. Corporate social responsibility reporting: A content analysis in family and non-family firms. J. Bus. Ethics 2015, 129, 511-534. [CrossRef] 
94. Chen, L.; Feldmann, A.; Tang, O. The relationship between disclosures of corporate social performance and financial performance: Evidences from GRI reports in manufacturing industry. Int. J. Prod. Econ. 2015, 170, 445-456. [CrossRef]

95. Mintzberg, H. Strategy-making in three modes. Calif. Manag. Rev. 1973, 16, 4-53. [CrossRef]

96. Scott, W.R. Institutions and Organizations; SAGE: Thousand Oaks, CA, USA, 1995.

97. Zahra, S.A. Environment, corporate entrepreneurship, and financial performance: A taxonomic approach. J. Bus. Ventur. 1993, 8, 319-340. [CrossRef]

98. Antoncic, B.; Hisrich, R.D. Corporate entrepreneurship contingencies and organizational wealth creation. J. Manag. Dev. 2004, 23, 518-550. [CrossRef]

99. Al Wakil, A. When Gambling is Not Winning: Exploring Optimality of VIX Trading under the Expected Utility Theory. J. Bus. Account. Financ. Perspect. 2018, in press. [CrossRef]

100. Bednarska, M.A. Complementary Person-environment fit as a predictor of job pursuit intentions in the service industry. Contemp. Econ. 2016, 10, 27-38. [CrossRef]

101. Russell, R.D.; Russell, C.J. An examination of the effects of organizational norms, organizational structure, and environmental uncertainty on entrepreneurial strategy. J. Manag. 1992, 18, 639-656. [CrossRef]

102. Tan, J. Regulatory environment and strategic orientations in a transitional economy: A study of Chinese private enterprise. Entrep. Theory Pract. 1996, 21, 31-47. [CrossRef]

103. Balabanis, G.; Katsikea, E. Being an entrepreneurial exporter: Does it pay? Int. Bus. Rev. 2004, 12, $233-252$. [CrossRef]

104. Goll, I.; Rasheed, A. Rational decision-making and firm performance: The moderating role of the environment. Strateg. Manag. J. 1997, 18, 583-591. [CrossRef]

105. Francis, J.; Collins-Dodd, C. The impact of firms' export orientation on the export performance of high-tech small and medium-sized enterprises. J. Int. Mark. 2000, 8, 84-103. [CrossRef]

106. Zahra, S.A.; Bogner, W.C. Technology strategy and software new ventures' performance: Exploring the moderating effect of the competitive environment. J. Bus. Ventur. 2000, 15, 135-173. [CrossRef]

107. Zahra, S.A.; Garvis, D.M. International corporate entrepreneurship and firm performance: The moderating effect of international environmental hostility. J. Bus. Ventur. 2000, 15, 469-492. [CrossRef]

108. Cohen, J. A power primer. Psychol. Bull. 1992, 112, 155-159. [CrossRef] [PubMed]

109. Faul, F.; Erdfelder, E.; Buchner, A.; Lang, A.G. Statistical power analyses using G* power 3.1: Tests for correlation and regression analyses. Behav. Res. Methods 2009, 41, 1149-1160. [CrossRef] [PubMed]

110. Morgan, N.A.; Kaleka, A.; Katsikeas, C.S. Antecedents of export venture performance: A theoretical model and empirical assessment. J. Mark. 2004, 68, 90-108. [CrossRef]

111. Cavusgil, S.T.; Zou, S. Marketing strategy-performance relationship: An investigation of the empirical link in export market ventures. J. Mark. 1994, 58, 1-21. [CrossRef]

112. Dimitratos, P.; Lioukas, S.; Carter, S. The relationship between entrepreneurship and international performance: The importance of domestic environment. Int. Bus. Rev. 2004, 13, 19-41. [CrossRef]

113. Robertson, C.; Chetty, S.K. A contingency-based approach to understanding export performance. Int. Bus. Rev. 2000, 9, 211-235. [CrossRef]

114. Etchebarne, M.S.; Geldres, V.V.; García-Cruz, R. El impacto de la orientación emprendedora en el desempeño exportador de la firma. ESIC Mark. Econ. Bus. J. 2010, 137, 165-220.

115. Chrisman, J.J.; Chua, J.H.; Sharma, P. Trends and directions in the development of a strategic management theory of the family firm. Entrep. Theory Pract. 2005, 29, 555-576. [CrossRef]

116. Sarstedt, M.; Ringle, C.M.; Smith, D.; Reams, R.; Hair, J.F., Jr. Partial least squares structural equation modeling (PLS-SEM): A useful tool for family firm researchers. J. Fam. Bus. Strategy 2014, 5, 105-115. [CrossRef]

117. Hair, J.F.; Hult, G.T.M.; Ringle, C.M.; Sarstedt, M. A Primer on Partial Least Squares Structural Equation Modeling (PLS-SEM); Sage: Thousand Oaks, CA, USA, 2017.

118. Jöreskog, K.G.; Wold, H.O. Systems Under Indirect Observation: Causality, Structure, Prediction 139; Elsevier: Amsterdam, The Netherlands, 1982.

119. Astrachan, C.B.; Patel, V.K.; Wanzenried, G. A comparative study of CB-SEM and PLS-SEM for theory development in family firm research. J. Fam. Bus. Strategy 2014, 5, 116-128. [CrossRef]

120. Henseler, J.; Ringle, C.M.; Sarstedt, M. A new criterion for assessing discriminant validity in variance-based structural equation modeling. J. Acad. Mark. Sci. 2015, 43, 115-135. [CrossRef] 
121. Ringle, C.M.; Wende, S.; Becker, J.M. Smart PLS 3; SmartPLS GmbH: Boenningstedt, Germany, 2015; Available online: https: / / www.smartpls.com (accessed on 30 March 2018).

122. Barclay, D.; Higgins, C.; Thompson, R. The partial least squares (PLS) approach to causal modeling: Personal computer adoption and use as an illustration. Technol. Stud. 1995, 2, 285-309.

123. Roldán, J.L.; Sánchez-Franco, M.J. Variance-based structural equation modeling: Guidelines for using partial least squares in information systems research. In Research Methodologies, Innovations and Philosophies in Software Systems Engineering and Information Systems (193-221); Mora, M., Gelman, O., Steenkamp, A., Raisinghani, M., Eds.; IGI Global: Hershey, PA, USA, 2012.

124. Carmines, E.G.; Zeller, R.A. Reliability and Validity Assessment; Sage Publications: Beverly Hills, CA, USA, 1979; Volume 17.

125. Fornell, C.; Larcker, D.F. Evaluating structural equation models with unobservable variables and measurement error. J. Mark. Res. 1981, 18, 39-50. [CrossRef]

126. Wright, R.T.; Campbell, D.E.; Thatcher, J.B.; Roberts, N. Operationalizing multidimensional constructs in structural equation modeling: Recommendations for IS research. Commun. Assoc. Inf. Syst. 2012, 30, 367-412.

127. Diamantopoulos, A.; Riefler, P.; Roth, K.P. Advancing formative measurement models. J. Bus. Res. 2008, 6, 1203-1218. [CrossRef]

128. Diamantopoulos, A.; Winklhofer, H.M. Index construction with formative indicators: An alternative to scale development. J. Mark. Res. 2001, 38, 269-277. [CrossRef]

129. Kleinbaum, D.G.; Kupper, L.L.; Muller, K.E.; Nizam, A. One Way Analysis of Variance. In Applied Regression Analysis and Other Multivariable Methods; PWS-Kent Publishing: Boston, MA, USA, 1988.

130. Chin, W.W. The partial least squares approach to structural equation modeling. Mod. Methods Bus. Res. 1998, 295, 295-336.

131. Hu, L.T.; Bentler, P.M. Fit indices in covariance structure modeling: Sensitivity to underparameterized model misspecification. Psychol. Methods 1998, 3, 424-453. [CrossRef]

132. Benavides-Espinosa, M.; Ribeiro-Soriano, D. Cooperative learning in creating and managing joint ventures. J. Bus. Res. 2014, 67, 648-655. [CrossRef]

133. Kolesnikov, Y.A.; Epifanova, T.V.; Usenko, A.M.; Parshina, E.; Ostrovskaya, V.N. The peculiarities of state regulation of innovation activities of enterprises in the global economy. Contemp. Econ. 2016, 10, 343-352. [CrossRef] 